\title{
BUMDESA (BADAN USAHA MILIK DESA) SEBAGAI KELEMBAGAAN PARTISIPATORIS UNTUK PENGEMBANGAN IDENTIFIKASI POTENSI MASYARAKAT PEDESAAN
}

\author{
Yuliana Windi Sari, S.Sosio,. M.Sosio \\ Dosen LB MKU Pancasila ITS; Dosen LB MKU Unair; \\ Team Leader Pendampingan \& Pemberdayaan Program Pengentasan Kemiskinan Kerjasama antara DPMD \\ Prov. Jatim - FISIP Unair \\ Yuliana.windyy@gmail.com
}

\begin{abstract}
ABSTRAK
Issue Pembangunan Daerah dewasa ini memerlukan peran partisipatoris kelembagaan yang mampu meningkatkan peran serta dari masyarakat desa, dimana peran kelembagaan ini diharapkan kedepannya mampu menjadi faktor yang mendorong terciptanya nilai-nilai gotong royong yang saat ini mengalami degradasi, karena melalui peran partisipatoris inilah, nantinya masyarakat desa diharapkan mampu menjadi penggerak dan bangkit untuk menciptakan ekonomi local dengan kultur local yang mampu berdaya saing dengan tuntutan jaman. Melalui Kebijakan strategis Pemerintah tentang Pembentukan dan Revitalisasi BUMDesa (Badan Usaha Milik Desa), diharapkan desain kelembagaan ini mampu mengakomodasi kepentingan masyarakat desa, baik kepentingan yang sifatnya ekonomis-produktif maupun kepentingan yang kontekstualisasinya berkaitan dengan pengembangan potensi lokal desa. Struktur, kultur masyarakat pedesaan yang berkembang dengan karakteristik homogen menjadi salah satu penghambat untuk menerima difusi dan inovasi melalui teknologi, oleh karena itulah diperlukan peran partisipatoris BUMDesa untuk melakukan identifikasi potensi lokal kelembagaan desa.
\end{abstract}

\section{PENDAHULUAN}

Potensi Masyarakat pedesaan yang dewasa ini menjadi sorotan utama pemerintah untuk dikembangkan sehingga potensi lokal tersebut dewasa ini digali sedemikian mungkin agar desa menjadi suatu wilayah yang mampu memberikan kontribusi pada Pendapatan Asli Daerah. Oleh karena itulah yang menjadi sorotan utama disini adalah terletak pada pengelolaan potensi desa menjadi suatu komoditas unggulan masyarakat pedesaan.

Pada Undang-undang No. 6 Tahun 2014 Bab IV tentang Kewenangan Desa dijelaskan bahwa desa memiliki kewenangan di bidang penyelengaraan Pemerintahan Desa, Pelaksanaan Pembangunan masyarakat desa, Pembinaan kemasyarakat pedesaan, pemberdayaan masyarakat pedesaan berdasarkan prakarsa masyarakat desa, hak asal usul dan adat istiadat desa.

Dalam hal ini desa memiliki otonomi dalam pengelolaan politik di pedesaan dan kehidupan masyarakat. Oleh karena itulah desa menjadi instrument yang dikembangkan oleh pemerintah pusat untuk mengimplementasikan berbagai kebijakan (Kemendesa, 2015). Termasuk kebijakan yang sekarang ini menjadi sorotan public yaitu tentang "Dana Desa" yang dikembangkan oleh Kementerian Pedesaan dan Daerah Tertinggal.

Peraturan Menteri Desa, Pembangunan Daerah Tertinggal dan Transmigrasi Nomor 21 Tahun 2015 tentang Penetapan Prioritas Pengunaan Dana Desa Tahun 2016, dalam konteks ini tertulis pada pasal 6 tentang prioritas pengunan Dana desa, antara lain : 
Pembangunan, Pengembangan, dan Pemeliharaan infrastruktur atau sarana dan prasarana fisik untuk penghidupan, termasuk ketahanan pangan dan pemukiman

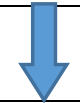

Pembangunan, Pengembangan dan Pemeliharaan sarana dan prasarana kesehatan masyarakat

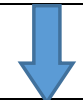

Pembangunan, Pengembangan dan pemeliharaan sarana dan prasarana pendidikan, sosial dan kebudayaan

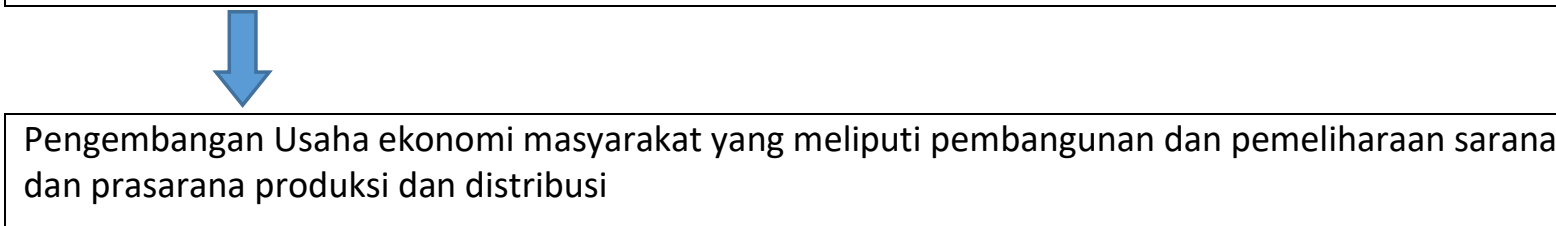
dan prasarana produksi dan distribusi

Pembangunan dan Pengembangan sarana dan prasarana energy terbarukan serta kegiatan pelestarian lingkungan hidup

Pada pasal 7 juga tertulis tentang tipologi desa berdasarkan tingkat perkembangan kemajuan desa, antara lain :

\section{TIPOLOGI DESA}

\begin{tabular}{|l|l|l|}
\hline Desa Tertinggal atau sangat & Desa Berkembang & Desa Maju atau Mandiri \\
tertinggal yang mengutamakan & memprioritaskan & memprioritaskan \\
pembangunan melalui & pembangunan sarana dan & pembangunan sarana dan \\
penyediaan sarana dan & prasarana pelayanan umum & prasarana yang berdampak \\
prasarana untuk pemenuhan & dan sosial baik pendidikan, & pada perluasan skala ekonomi \\
kebutuhan atau akses & kesehatan untuk & dan investasi desa termasuk \\
kehidupan masyarakat desa & mengembangkan potensi dan & membuka lapangan pekerjaan, \\
& kapasitas masyarakat desa & padat karya teknologi tepat \\
& & guna, dan investasi melalui \\
& & pengembangan BUMDesa \\
\hline
\end{tabular}

\section{STRUKTUR PEMERINTAHAN MASYARAKAT PEDESAAN}

Secara struktur pemerintahan masyarakat desa pada hirarki tertinggi yaitu kepala desa sebagai penguasa yang berada pada ranah pedesaan oleh karena itulah politik di pedesaan identik dengan kekuasaan kepala desa, dalam hal ini kepala desa merupakan penguasa secara formal yang memiliki kewenangan dalam mengatur desa. Sedangkan kekuasaan informal lebih terpusat pada peran dari tokoh-tokoh masyarakat desa setempat, definisi kekuasaan inilah yang menjadikan masyarakat desa memiliki karakteristik tersendiri yang menunjukkan identitasnya.

Dalam konteks adanya alokasi dana desa, dijelaskan bahwa desa memiliki kewenangan utama sebagai ujung tombak pelaksanaan program dana desa, akan tetapi kepala desa bukan satu-satunya pemeran utama karena terdapat pendamping dana desa yang akan membantu pada aspek pengelolaan. Oleh karena itulah, yang menjadi sorotan utama disini adalah apakah keberadaan dana 
desa tidak menjadikan suatu benturan nilai-nilai lokal dan politis terutama dalam aspek pengelolaannya (Heru, 2001).

\section{ASPEK PENGELOLAAN KELEMBAGAAN MASYARAKAT PEDESAAN}

Pada tipologi desa yang tergolong pada Desa Mandiri diketahui bahwa desa tersebut adalah klasifikasi desa yang memiliki kemungkinan untuk perluasan perekonomian masyarakat pedesaan melalui BUMDesa (Badan Usaha Milik Desa). BUMDesa diharapkan menjadi salah satu wadah dalam pengembangan potensi lokal masyarakat Pedesaan, secara regulasi BUMDesa juga telah diatur dalam Permendesa No. 5 Tahun 2014.

Keterkaitan antara kelembagaan masyarakat pedesaan dengan politik identitas adalah penekanan pada aspek kearifan lokal yang seharusnya menjadi pijakan dalam pengelolaan BUMDesa karena sejatinya suatu lembaga pedesaan dilakukan berdasarkan pemahaman dan simbolisasi politik masyarakat pedesaan, sehingga BUMDesa bisa menjadi lembaga pedesaan yang dapat memberikan kontribusi pada kehidupan masyarakat pedesaan.

Pemberdayaan Masyarakat desa melalui BUMDesa menjadikan desa sebagai salah satu instrument yang seolah-olah dirancang memiliki identitas yang seragam oleh karena itulah yang menjadi sorotan utama disini adalah Bagaimana BUMDesa mampu memberikan kontribusi untuk membingkai kearifan local pada kehidupan masyarakat pedesaan.

\section{KULTUR, STRUKTUR DAN KEHIDUPAN MASYARAKAT PEDESAAN.}

Berdasarkan data yang diakses dari website Badan Pemberdayaan Masyarakat Provinsi Jawa Timur, bahwa selama tahun 2015 terdapat 13 BUMDesa yang tersebar di 13 Kabupaten di Provinsi Jawa Timur yang mendapatkan dana pemberdayaan yang dikelola oleh BUMDesa.

\begin{tabular}{|c|c|c|}
\hline NO & LOKASI & ALOKASI \\
\hline 1 & $\begin{array}{l}\text { Pemerintah Desa Tasikmadu, Kec.Watulimo, Kab. } \\
\text { Trenggalek }\end{array}$ & $75,000,000$ \\
\hline 2 & $\begin{array}{l}\text { Pemerintah Desa Kalidawir, } \\
\text { Kec. Kalidawir, Kab. Tulungagung }\end{array}$ & $75,000,000$ \\
\hline 3 & $\begin{array}{l}\text { Pemerintah Desa Sumberingin, } \\
\text { Kec. Sanankulon, Kab. Blitar }\end{array}$ & $75,000,000$ \\
\hline 4 & $\begin{array}{l}\text { Pemerintah Desa Jatiguwi, } \\
\text { Kec. Sumberpucung, Kab. Malang }\end{array}$ & $75,000,000$ \\
\hline 5 & $\begin{array}{l}\text { Pemerintah Desa Paleran, } \\
\text { Kec. Umbulsari, Kab. Jember }\end{array}$ & $75,000,000$ \\
\hline 6 & $\begin{array}{l}\text { Pemerintah Desa Kemlagi, } \\
\text { Kec. Kemlagi, Kab.Mojokerto }\end{array}$ & $75,000,000$ \\
\hline 7 & $\begin{array}{l}\text { Pemerintah Desa Kincang Wetan, } \\
\text { Kec. Jiwan, Kab. Madiun }\end{array}$ & $75,000,000$ \\
\hline 8 & $\begin{array}{l}\text { Pemerintah Desa Sumengko, Kec.Kalitidu, Kab. } \\
\text { Bojonegoro }\end{array}$ & $75,000,000$ \\
\hline 9 & $\begin{array}{l}\text { Pemerintah Desa Sendangharjo, } \\
\text { Kec. Brondong, Kab. Lamongan }\end{array}$ & $75,000,000$ \\
\hline 10 & $\begin{array}{l}\text { Pemerintah Desa Prekbun, } \\
\text { Kec. Pademawu, Kab.Pamekasan }\end{array}$ & $75,000,000$ \\
\hline 11 & Pemerintah Desa Kedungturi, Kec.Taman, Kab Sidoarjo & $75,000,000$ \\
\hline 12 & $\begin{array}{l}\text { Pemerintah Desa Lembengan, Kec.Ledokombo, Kab. } \\
\text { Jember }\end{array}$ & $75,000,000$ \\
\hline
\end{tabular}


Berdasarkan data diatas diketahui bahwa BUMDesa merupakan lembaga yang memiliki kapasitas untuk meningkatkan kesejahteraan masyarakat pedesaan. Pemerintah Provinsi Jawa Timur telah memberikan kontribusi pada terhadap pengembangan usaha BUMDesa akan tetapi yang perlu dikritisi bukan pada jumlah alokasi dana yang diperlukan akan tetapi pada penggunaan dana tersebut bagaimanakah dana tersebut dikelola dan dijadikan suatu modal untuk penguatan kapasitas BUMDesa sebagai lembaga perekonomian masyarakat pedesaan.

Program-program yang menjadikan desa sebagai instrument untuk pengelolaannya bukan hanya penguatan kapasitas BUMDesa akan tetapi juga berkaitan dengan program-program lain seperti halnya ADD (Alokasi Dana Desa), Program Jalinmatra (Jalan Lain Menuju Mandiri dan Sejahtera) sejatinya program-program tersebut dirancang untuk membangkitkan potensi local masyarakat pedesaan dengan memberikan stimulus agar desa bisa memberikan respon terkait program yang dilakukan serta menjadikan desa sebagai ujung tombak untuk mengentaskan permasalahan kesenjangan.

Program yang ditawarkan oleh Pemerintah dalam rangka memberantas kemiskinan khususnya di kawasan pedesaan tidak hanya memberikan suatu solusi tetapi berbagai solusi, akan tetapi program-program tersebut seharusnya memperhatikan kondisi kultural masyarakat desa setempat sehingga program tidak hanya berjalan pada saat itu akan tetapi juga menjadi program yang berkelanjutan.

Politik identitas menjadi suatu simbol bahwa setiap daerah dan wilayah memiliki karakteristik tersendiri oleh karena itulah tidak menutup kemungkinan bahwa politik di wilayah pedesaan juga memiliki identitas yang berbeda dengan politik yang di wilayah yang bukan pedesaan (Kemendargri, 2010). Dalam kaitannya dengan BUMDesa perlu diketahui bahwa dana yang diberikan pemerintah provinsi ke BUMDesa tidak serta merta dapat diseragamkan karena setiap desa memiliki potensi local dan nilai-nilai kearifan lokal tersendiri dalam pengelolaan BUMDesa, sehingga apa yang diharapkan pemerintah terhadap BUMDesa merupakan salah satu kebijakan yang tepat dikarenakan BUMDesa memiliki tujuan untuk membangkitkan potensi local masyarakat pedesaan yang pada akhirnya membuat masyarakat desa memiliki hasrat untuk membangkitkan potensinya. Politik identitas memiliki relevansi dengan potensi desa terutama dalam identifikasi potensi masyarakat oleh karea itu ciri khas dan identitas merupakan hal yang significant dalam menganalisa tentang kelembagaan BUMDesa.

Politik identitas merupakan salah satu bentuk eksistensi suatu daerah karena melalui politik identitas suatu daerah tersebut memiliki symbol bahwa mereka berbeda dengan daerah lainnya, oleh karena itulah yang perlu menjadi catatan utama disini adalah politik identitas harus berjalan dengan potensi local agar mendapatkan dukungan dan legitimasi dari masyarakat. Seperti halnya BUMDesa yang seharusnya didukung oleh potensi lokal yang mencerminkan identitas suatu desa, karena BUMDesa adalah lembaga yang secara umum dibentuk oleh sutu program sehingga jika program tersebut telah habis masanya, seharusnya potensi local dan politik identitas tersebutlah yang menjadikan BUMDesa sebagai suatu lembaga yang berdaya dengan kekuatan potensi local dan didukung sumberdaya serta mendapatkan legitimasi dari politik identitas.

\section{KESIMPULAN}

Issue pembangunan saat ini menjadi sorotan adalah bagaimana agar konseptualisasi pembangunan bersifat "Bottom up" sehingga arah kebijakan pembangunan tidak hanya menekankan pada aspek kebijakan strategis akan tetapi juga menciptakan "Pembangunan \& Peradaban", salah satu issue sentral yang saat menjadi agenda Pemerintah adalah Pembangunan Pedesaan, melalui BUMDesa (Badan Usaha Milik Desa), peran partisipatoris kelembagaan inilah diharapkan mampu 
memberdayakan potensi-potensi kawasan pedesaan yang selama ini belum teridentifikasi. Identifikasi potensi lokal melalui kelembagaan BUMDesa misalnya "Desa Wisata", dengan konsep yang demikian maka diharapkan masyarakat desa mampu mengatasi keterbatasan akses, ekonomi dan yang utama adalah pembangunan tidak hanya bersifat struktural tetapi pembangunan juga dilakukan melalui pendekatan yang sifatnya humanis.

\section{DAFTAR PUSTAKA}

Heru, N. (2001). Uang, Rentenir dan Hutang Piutang di Jawa. Yogyakarta: Pustaka Pelajar. Kemendargri. Peraturan Menteri Dalam Negeri No. 39 Tahun 2010 tentang Badan Usaha Milik Desa BUMDesa Perkuat Ekonomi Desa (2010). Indonesia.

Kemendesa. Peraturan Menteri Desa Pembangunan Daerah tertinggal dan Transmigrasi No.4 Tahun 2015 tentang Pendirian, Pengurusan, dan Pengelolaan dan Pembubaran Badan Usaha Milik Desa, Pub. L. No. 4 (2015). Indonesia. 